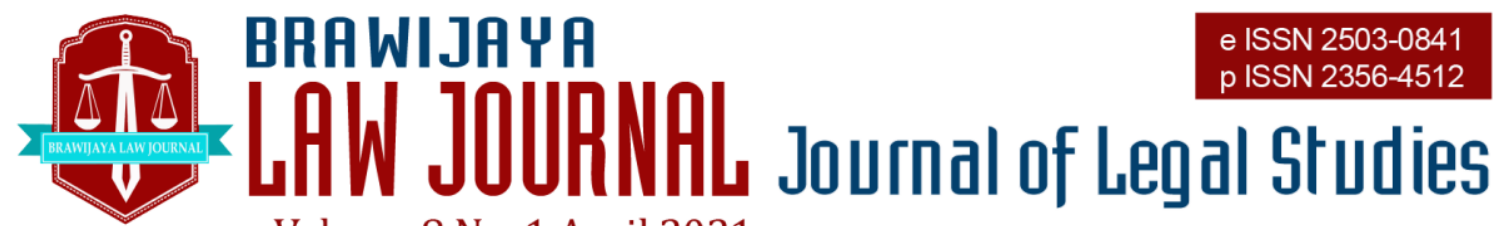

Volume 8 No. 1 April 2021

Nationally Accredited No. 30/E/KPT/2018 Dated 24th October 2018

This work is licensed under a Creative Commons Attribution-NonCommercial 4.0 International License

\title{
Modus of Girls Trafficking in Bongas Indramayu: Victimology Perspective
}

\author{
Hamja, Hamja ${ }^{\text {a }}$, Faizin Sulistio ${ }^{\mathrm{b}}$ \\ ${ }^{a}$ Faculty of Law Universitas Wiralodra Indramayu \\ Email: hamja.hamja904@gmail.com \\ ${ }^{\mathrm{b}}$ Faculty of Law Universitas Brawijaya \\ Email: faizin@ub.ac.id
}

Submitted : 2021-03-12 | Accepted : 2021-04-28

\begin{abstract}
The Regency of Indramayu has been stigmatised as a land of trafficking of women and children, not only at national level, but it has also transcended overseas. This research is aimed to seek deeper into the perspective of the victims from Bongas, Indramayu regarding their involvement in the trafficking. This research employed case study method and field observation based on descriptive-analytical approach. This research reveals that the majority of the people in Indramayu are living in the breadline, and they are mostly poorly educated. Women in Indramayu are even denounced as the breadwinner, or locally called as "luruh duit" or rushing for money, and this term is inappropriately interpreted; women are burdened with the responsibility to raise the economic status of the families by working in big cities. The culture of earning money by migrating to big cities is seen as a chance for human trafficking. This research also suggests some strategies such as co-assisting and developing the program to identify, rehabilitate, and reintegrate the victims of the crime.
\end{abstract}

Keywords: girls; victim; human trafficking.

\section{INTRODUCTION}

Study on crime victims conducted by Van Dijk and Stenmetz (1980) in the Netherlands indicates that women are less likely than men to be the victim, but the former have higher criminal risks for crimes such as rape. Despite the low number of victims for women, women tend to conceal what they have experienced compared to men. Roy Morgan Research Centre (1997)

Rima Astuti, 'Hubungan Kesadaran Akan Kerentanan Diri dan Mekanisme Coping Pada Perempuan Pekerja Malam di Tempat Hiburan found that $79 \%$ of women surveyed feel in danger being in public places at night, while Women's Safety Survey found out that $52 \%$ of women feel threatened when waiting for public transport alone at night. Women are considered prone to being crime victims. ${ }^{1}$

In line with the above perspective, although the figure for female victims in most criminal cases is smaller than that of men, the figure can be higher for women as

Karaoke di Wilayah Jakarta Barat', (2011) 7(11)

Jurnal Kriminologi Indonesia, p. 193. 
victims in a criminal case. Women are often positioned as subordinates and they are likely to be vulnerable to trafficking. ${ }^{2}$ In a wider scope, victims are regarded as those suffering or harmed due to violation of criminal law or non-criminal law. On the other hand, in a more specific definition, victims are understood as those suffering from criminal offenses.

Logically, it can be understood that crime victims have their right to protection. Firstly, this protection is intended to give time of recovery to the victims concerned and to anticipate any intention of uncontrolled revenge. The state takes over the victim's role in filing a charge with the intention to minimise potential of revenge and for the sake of criminal sentences based on rational consideration. Secondly, it is constitutional responsibility of a state to protect the victims since it is the objective set by the state that aims to guarantee the life of the citizens and welfare. Victims are those who are harmed, and they do not receive enough attention and this fact has carried them away further from judicial system. ${ }^{3}$

Victimisation mostly takes young women in human trafficking, especially those with economic burden, issues in education, and lack of religious knowledge. ${ }^{4}$ Several issues have put girls in the trafficking. The issues causing this victimisation have mainly triggered the trafficking as what happened in Bongas, the

2 Q. Zaman, 'Sanksi Pidana Perdagangan Perempuan (Women Trafficking) (Studi Komparatif Antara Undang-undang Nomor 21 Tahun 2007 Tentang Pemberantasan Tindak Pidana Perdagangan Orang dan Hukum Islam', Raheema, (2017) 2(3) Jurnal Studi Gender dan Anak, p.17.

3 Lilik Mulyadi, Kapita Selekta Hukum Pidana, Kriminologi dan Viktimologi, (Jambatan, Jakarta, 2007), p. 127-132.

4 Anis Soraya, 'Binahayati Rusyidi dan Maulana Irfan, 'Perlindungan Terhadap Anak dan Korban
Regency of Indramayu. However, economic, educational, and religious factors no longer seem to be the significant factors triggering trafficking, but social gaps, consumptive and instant way of life seems to have replaced those factors. ${ }^{5}$ All these new factors have demotivated their desire in education, but they rather choose to work and earn money on their own instead of having to meet complicated requirement to study in formal institutions.

Similarly, Forrel ${ }^{6}$ states "trafficking is motivated by money", and traffickers are also motivated by money. This sentence gives us understanding that economic factor serves as one of the main factors of crime due to economic gap (social gap). Such an issue triggers people to seek for a job even when they must migrate to another city to get the job. Gary Becker from University of Chicago argues that a person tends to commit a crime since the profit he/she gains may be more promising than that obtained from other more acceptable jobs. Therefore, some are found to prefer being an offender due to the promising profit. ${ }^{7}$ In reference to the issues above, this research is aimed to find out to what extent trafficking of women in Bongas, Indramayu is understood from victims' perspective.

\section{LEGAL MATERIALS AND METHODS}

This research employed case study method and field observation based on

Trafficking', (2017) 2(1) Prosiding KS. Riset, PKM, p. 79.

5 An interview with a staff of Kusuma Bongas Foundation, Sulistiani Andan Dewi on the $16^{\text {th }}$ of December 2019 in Bongas, Indramayu

6 Everd Scor Rider Daniel, Nandang Mulyana, Budhi Wibawa, 'Human Trafficking di Nusa Tenggara Timur', (2016) 7(1) Jurnal Social Work, p. 26.

7 Tubagus Ronni Nitibaskara, Catatan Kriminalitas, (Jayabaya Univercity Press, 1999), p. 50. 
descriptive-analytical approach. The research technique is explorative, in which it is designed to develop the perspective about the case of trafficking by investigating the case to obtain the flow of the process. The research design is intended to position this trafficking case as the primary case or single case rigorously studied within the social system in which trafficking practices take place. This is aimed to describe all the elements involved in the trafficking.

Analysis unit in this research involves: persons, families, and social groups in the society, in which persons comprise 1) the young victims of trafficking recruited, collected, accommodated, sent, trafficked, and employed by particular parties by violating the law without any approval or consent of other parties or of the children involved as the victims; 2) the traffickers under arrest or detained by the police or prosecutors or those still in operation; 3 ) local apparatuses and policy implementers responsible for prevention and countermeasures of trafficking of women and children in the government of Indramayu; and 4) families, comprising the members of the families of the victims. The families are those having a kinship or within married ties with the victims. Social groups are the members of public in the society.

As for the data collection techniques, the primary data was obtained from in-depth interviews following the guidelines prepared and the secondary data was obtained from several organisations related with trafficking issues. Furthermore, the collected data in the study was analysed by means of descriptive analysis through understanding (vestehen) to profoundly investigate the meaning or definition of the trafficking case that wholly took place. In terms of inferences or conclusion, discussions took place and were attended by the researchers and informants in which subjective data was further studied to allow them to be more understood.

\section{RESULTS AND DISCUSSION}

Victimology is an English term for Victimology which comes from the Latin word Victima which means victim and logos which means study / science. Victim is a person who has suffered physical or mental suffering, loss of property or resulted in death for an act or attempted minor offense committed by the perpetrator of a criminal act and others ${ }^{8}$. In line with the above opinion is Arief Gosita, which states that what is meant by the victim is a person who suffers physically and spiritually as a result of the actions of others seeking self-fulfilment or other people who are contrary to the interests and rights of those who suffer. In addition, victims are people who individually or in groups have suffered losses, including physical or mental injuries, emotional pain, economic loss or actual deprivation of their basic rights, either because of their actions (by act) or because of negligence (by omission).

According to Muladi, what is meant by victim is someone who has suffered losses as a result of a crime and or whose sense of justice has been directly impaired as a result of his experience as a target or target of crime. In simple terms, the definition above can be translated, victims of crime are people who either individually or collectively, suffer losses due to actions or do not do anything that violates the criminal law in force in a country, including regulations that prohibit abuse of power. Completely victims of

8 Didik M.Arief Mansyur dan Elisatris Gultom, Urgensi Perlindungan Korban Kejahatan: Antara 
criminal acts are "people who individually or collectively have experienced suffering, including physical or mental suffering, emotional pain, economic loss, or substantial impositions, human rights, through actions or omission [ that violates criminal or criminal law. Crime here is that each of these acts is given a criminal sanction for violating the norms of society's expectations of which behaviour is appropriate as a citizen. JE Sahetapy stated that what is meant by victims is an individual, a legal entity who has suffered injuries, damages or other forms of loss that are felt both physically and psychologically. This problem is not only seen from a legal standpoint, but also from an economic and political perspective, as well as from a social and cultural perspective. Those who become victims in this case can be due to the fault of the victim himself, the role of the victim directly or indirectly, and without the role of the victim ${ }^{9}$.

Based on the relationship between the perpetrator and the victim's accountability, Stephan Schafer presents the typology of victims into seven forms, namely:

a. Unrelated victims are those who have no connection with the perpetrator and become victims because they are potential. For this reason, from the aspect of responsibility it rests entirely on the side of the victim.

b. Provocative victims are victims caused by the role of the victims themselves to trigger crimes. Therefore, from the aspect of responsibility lies with the victim and the perpetrator together.

c. Participating victims. The victim's actions are unconsciously able to encourage the perpetrator to commit crimes. For example, taking large amounts of unattended money from the bank, then wrapped it in a plastic bag so as to encourage people to seize it. In this aspect, the full responsibility lies with the perpetrator.

d. Biologically weak victims are crimes caused by the physical condition of the victims, such as women, children, and elderly people, who are potential victims of crime. In terms of the aspect, the responsibility lies with the community or the local government because they cannot provide protection to helpless victims.

e. Socially weak victims are victims who are not paid attention by the community concerned, such as homeless people with a. weak social position. For that reason, the full responsibility lies with the criminals or society.

f. Self-victimizing victims are victims of crimes committed by themselves (false victims) or crimes without victims. For this reason, the full responsibility lies with the victim because he is also the perpetrator of the crime.

g. Political victims are victims because of their political opponents. Sociologically, this type of victim cannot be accounted for unless there is a change in the political constellation.

Victimology studies undergo three phases of development. Initially, victimology studied only victims of crime. In this phase, it is said to be penal or special victimology. In the second phase, victimology not only examines the problem of crime victims but includes accident victims. In this phase it is called general victimology. The third phase, victimology has developed more broadly,

9 J.E.Sahetapy, Victimologi: Sebuah Bunga Rampai, (Jakarta: Sinar Harapan, 1987), p. 25. 
namely examining the problems of victims of abuse of power and human rights, in this phase it is said to be new victimology. The development of this Victimology is inseparable from previous thinkers, namely Hans Von Henting, a criminologist in 1941 and Mendelsohn in 1947. According to JE Sahet, the scope of victimology study includes how a person (can) be a victim determined by a victim that is not always related to the problem of crime. This includes victims of accidents and disasters apart from victims of crimes of abuse of power. JE Sahetapi, also argues that criminology and victimology are interrelated sides of a coin. Attention to the crime that exists should not only revolve around the emergence of crime but also the consequences of crime, because from this it will appear that attention shifts not only to the perpetrator of the crime but also to the position of the victim of the crime. This is also discussed by other legal experts in paying attention to this relationship, or at least the attention to the occurrence of crime is not only from one point of view, if someone becomes a victim of crime, it is clear that a crime has occurred, or there is a victim of crime and there is a crime there is a victim. So, if you want to describe and prevent crime, you must pay attention to and understand the victims of a crime, but people's habits only tend to pay attention to the perpetrators of the crime.

Victimology and criminology studies have a starting point at understanding a criminal victimization, namely victimization from the perspective of the victim. victimization, among others, can be formulated as an accumulation of suffering (mental, physical, social, economic, moral) on certain parties and from certain interests. According to JE Sahetapy, victimization is suffering, both physically and psychologically or mentally related to the actions of other parties. In victimology, it is also known as a double victim, namely victims who experience various kinds of suffering such as mental, physical, and social suffering, which occur when the victim experiences a crime after and at the time the case is examined and after the completion of the court.

In addition, JE Sahetapy argues that the victimization paradigm includes:

a. Political victimization can include aspects of abuse of power, rape of human rights, interference of armed forces outside of their functions, terrorism, intervention and warfare locally or on an international scale.

b. Economic victimization, especially those that occur due to collusion between the government and conglomerates, the production of goods that are not of good quality or that damage health, including environmental aspects.

c. Victimization of the family, such as rape, torture, against children and wives and neglect the elderly or their own parents.

d. Victimization of the media, in this case can be called drug abuse, alcoholism, malpractice in the field of medicine and others.

e. Juridical victimization, this dimension is quite broad, both concerning the aspects of the judiciary and correctional institutions as well as those concerning the dimensions of discrimination in legislation, including applying power and stigmatization even though the judicial aspects have been resolved.

Victimology with its various views broadens the theory of criminal ethology which is needed to better understand the existence of crime as a structural and non- 
structural victimization. In addition to the views in victimology, it encourages people to pay attention to and serve everyone who can become victims mentally, physically, and socially. This victimology can understand the position of the victim as the basic cause of crime and seek the truth. In seeking the truth and to understand the problem of evil, delinquency and deviation are a dimensionally true proportion.

In general, victimology studies have several benefits, namely:

a. Benefits relating to defending victims' rights and legal protection.

b. Benefits relating to the explanation of the victim's role in a crime.

c. Benefits relating to efforts to prevent victims.

According to Ezzat Abdel Fattah, from the perspective of victim involvement in the occurrence of crimes, there are several forms of victims, namely:

a. Non-participating victims are those who do not deny / reject crime and criminals but do not participate in the prevention of crime.

b. Latent or predisposed victims are those with certain characteristics which tend to become victims of certain violations.

c. Provocative victims are those who cause crime or trigger crime.

d. Participating victims are those who are not aware or have other behaviours that make it easier for themselves to become victims.

e. False victims are those who are victims because of themselves.

Apart from that, Sellin and Wolfgang also divided it as follows: a. Primary victimization, what is meant by individual victims. So, the victim is an individual (not a group).

b. Secondary victimization, the victims are groups, such as legal entities.

c. Tertiary victimization, the victims are the wider community.

d. Mutual victimization, the victims are the perpetrators themselves, for example prostitution, adultery, and narcotics.

e. No victimization, what is meant is not that there are no victims, but the victims cannot be immediately identified. For example, consumers are tricked into using a product ${ }^{10}$.

Based on the above, it shows that in a crime there is the involvement and responsibility of the victim himself so that a crime occurs. Victims can have a functional role in the occurrence of a crime, whether consciously or unconsciously, directly or indirectly. The role in question is the attitude and condition of a person who will become a potential victim or attitudes and circumstances that can trigger someone to commit a crime. This is in line with Hentig's opinion, which states that the role of victims in causing crime is:

a. The crime was intended by the victim to occur.

b. Losses due to crime may be used by the victim to get a bigger profit.

c. The adverse effect of the victim may be a collaboration between the perpetrator and the victim.

d. Losses due to a crime actually do not occur if there is no provocation of the victim.

In Law No. 31 of 2014 the definition of a victim is a person who experiences physical, mental, and / or economic loss as a

10 Lilik Mulyadi, above n 3, p. 120 
result of a criminal act. The limits on crime victims can be described as follows:

a) Judging from its nature, there are individuals and collectives. Individual victims can be identified easily so that victim protection can be done in a real way, but collective victims are more difficult to identify. However, Law No. 23/1997 on Environmental Management provides a way out in the form of demanding compensation through class actions.

b) Judging from the losses, it can be suffered by a person, community group and the wider community. In addition, victims' losses can be material in nature which can be assessed in money and immaterial, namely feelings of fear, sadness, psychological shock.

Hans Von Hentig divides several types of vulnerable victims, namely ${ }^{11}$ :

a. The young: Children, because of their spiritual and physical weakness and immature personalities, do not have enough resistance to face the attacks of adults. They are not only victims of the criminal act of property, but can also become sexual victims of both men and women.

b. The female: Women, because of their weaknesses are easy to become victims, easy women often become victims of murder after experiencing rape, old women because they are considered rich so that they become victims of criminal acts against assets.

c. The old: Parents, usually tend to start accumulating property, have the risk of becoming victims of crimes against their property. Hentig said that the older generation on the one hand hold / have accumulated wealth, on the other hand there are weaknesses both physically and mentally. In this situation there is a danger of becoming a victim risk.

d. The mentally defective and other mentally deranged: Crazy people, drinkers, drug addicts, psychopaths; because under such conditions it is certainly impossible to sustain a criminal attack. Hentig said of all male murder victims $\pm 66 \%$ (approximately sixty-six percent) were alcoholics, and it was found that approximately $\pm 70 \%$ (approximately seventy percent) of the murder victims were in fact drunk.

e. Immigrants: Immigrants, this group has a lot of risk of becoming victims of various kinds of crime, robbery, fraud. This is due to some of the difficulties they face in interacting with the new language and culture in their place. This kind of situation is often used negatively by certain groups to get wants or benefits.

f. Minorities: Minorities, this group is almost the same as immigrants, it's just that the difference lies in the kind of assumption that they are not equal before the law when compared to the majority group. The racial assumption of the majority group tends to increase the risk of becoming a victim.

g. Dull normal: Stupid people, this group has the risk of becoming a victim from birth, because the level of intelligence is below average.

Hukum Nasional Departemen Kehakiman RI, 1991), pp. 11-12 
f. The depression: Depression, people who are constantly depressed in their lives will experience deterioration of their physical and mental strength. In these conditions they are at risk of becoming victims because they tend to be apathetic and surrender, there is no nature to fight and attack because of their weak self-confidence.

g. The acquisition: Greedy, a person who is greedy is easy to trap, deceive, or take advantage of because of his greed for property or position.

h. The wanton: Neglectful, careless people or people tend to have the risk of becoming victims because of their careless nature.

i. The lonesome and the heart broken: Lonely and heartbroken, people who are in such a situation have the potential to become victims of crime, can be deceived, and easily taken advantage of because of their mood instability;

j. The tormentors: Violent, people who have a high or violent temperament and like to abuse are at risk of becoming victims. An example of a husband who often hurts his wife, is often the victim of murder committed by his own children with a motive of revenge.

k. The blocked, exempted and fighting: Closed, someone who is blocked or someone who is in a very difficult position and condition to get out of danger. This group has the potential to experience the risk of crime

12 Indra Yohanes Killing dan Beatriks Novianti Killing-Bunga, 'Motif, Dampak Psikologis, Dan Dukungan Pada Korban Perdagangan Manusia Di Nusa Tenggara Timur,'(2014) 10(10) Jurnal Psikologi Ulayat, p. 14. because it is difficult to get help from the authorities

Meanwhile, the protective model for crime victims, namely: First, procedural rights, this model emphasizes the active role of victims in criminal justice processes, such as assisting the Public Prosecutor in every level of case examination. The victim is the party whose opinion must be heard. Second, compensation and restitution, a service model that emphasizes the provision of compensation in the form of compensation and restitution and efforts to restore the condition of victims who have experienced trauma, fear and depression due to crimes, as regulated in Law Number 31 of 2014 concerning Witness Protection and Victim.

Trafficking of women represents a social issue that interrupts the stability of social life. It can even cause mental disorder due to traumatising effect. Research findings ${ }^{12}$ imply that the victims of human trafficking receive enough attention from the law but not enough psychological care. It will be easier for scientists in psychology to develop their scientific findings when practitioners are keen to transform their findings in the field into scientific papers. Such awareness should be the responsibility of all parties for the recovery of the victims. On the other hand, Priyono Adi ${ }^{13}$ argues that trafficking of women brings effects to the victims (1) physically such as (a) mild or serious physical injuries,(b) disabilities, (c) unwanted pregnancy, (d) communicable diseases, (c) sexually transmitted diseases, (f) HIV and AIDS, (g) death, psychologically such as (a) lack of self-

13 Rizka Ari Satriani, Tamsil, Muis, 'Studi Tentang Perdagangan Manusia (Human Trafficking) Pada Remaja Putri Jenjang Sekolah Menengah di Kota Surabaya', (2013) 4(1) Jurnal BK UNESA, p. 69. 
confidence, (b) feeling of helplessness, (c) irrational feeling of fear, (d) trauma, (e) mental illness or stress, or (3) sexually such as loss of virginity, or socially such as being ostracised from society. From all those impacts, physical impacts such as unwanted pregnancy, sexually transmitted diseases, HIV and AIDS are commonly found in the victims of trafficking. The following are several examples of cases of trafficking in Bongas Indramayu.

The first case involves Mawar. Mawar (not her real name) is the only child. Her father works in a garage in Jakarta but never sends part of his earning to his family and he earns uncertain amount of money. Her mother works as a peasant and earns uncertain amount too, depending on the workload she gets. Mawar lives with her mother. Upon her secondary school graduation, she decided not to continue her further education due to economic factor. Mawar was offered a job by a man named Budi (not his real name) from Eretan village. Her parents urged her to take his offer, but they had to spend 5 million rupiahs to get the job. Furthermore, Mawar was taken to Daan Mogot, west Jakarta on the $5^{\text {th }}$ of November 2015. Mawar was introduced to a café manager called Ling Lung (not his real name), a chinese descendant. Following the introduction, Mawar was taken upstairs to her room at about 15.00 WIB. She was asked to take a shower and to put some makeup as if she were prepared for work; Mawar did as asked. Mawar mingled with other new friends. During the night, Mawar accompanied four men for IDR 300,000 each, but she was only given IDR 100,000 per guest. Mawar worked every day serving three to six men for a month. She complained she was not well, and her parents asked her to come back home. On the $29^{\text {th }}$ of December 2015 Mawar was on her way back home seriously ill. She was taken to the doctor upon her arrival, but she seemed to get even worse. Her mother decided to take her to Bhayangkara Hospital of Losarang Indramayu. She was tested HIV and the result came reactive, B20".

The second case involves Bunga. Bunga (not her real name) only has a sister. Her parents were divorced when Bunga was a little child. Her mother is a housewife who does not earn much. She is mentally ill, and both Bunga and her mother live with her grandfather. After her graduation from secondary school, Bunga stopped going to school since she did not have money for further education. Bunga helped her parent doing house chores, but this tedium of working at home forced her to have a desire to work outside home to support the family. Dahlia (not a real name), Bunga's friend, came to offer a job in Jakarta as a maid for a pimp in a brothel in Kalijodo. She was interested in taking the offer. Bunga left for Jakarta in December 2015 with her friend by public transport on her own money. Upon her arrival in Jakarta, Bunga went straight to her friend's place and stayed for two days. In the following day, Bunga saw Ojay, the person for whom Bunga worked in Kalijodo. Unfortunately, Bunga did not receive her wages until the brothel house in Kalijodo was shut. In panic of getting no money, Bunga contacted her friend and decided to stay there for a second time while waiting for her withheld wages from Ojay. Knowing the fact that Bunga did not have any money left, Ojay offered Bunga to be a laundress in the neighbourhood and she was forced to take the job since she needed money to survive. With her new job, Bunga did not get money regularly since it depended on the availability of customers. Bunga was paid only IDR 15,000 per laundry basket. Bunga had to pay for her rent as much as IDR 500,000 per 
month while the withheld wages from Ojay never came and no one knew his whereabouts. Since Bunga had no more money left to pay for the rent, Bunga started to miss her hometown and decided to contact her parents. Hearing her condition, the family back in hometown was in panic and perplexed by the question of how to pick her up from Jakarta. Bunga shared her condition with her friend and her friend tried to bring her to Kusuma Bongas Foundation.

Those two cases indicate that trafficking issues represent a new form of slavery in a modern world. ${ }^{14}$ Those also clearly indicate that vulnerable young women often becoming the victims of trafficking come from poorly educated and broken families facing economic hurdles. This environment has shaped vulnerability of the victims. Poor education presents a barrier to information, and it is even worse when they live in a very remote area. This unfortunate situation has made them prone to deceit by an irresponsible individual, the one involved in trafficking of women. 15 Trafficking of women in the district of Bongas Indramayu during which this research was conducted was considered serious since countless young women aged 17 years old served as migrant labours both domestically and overseas. Some were positioned in Jakarta, Batam, Surabaya, and Bali and some others were in Malaysia, Singapore, Korea, and Hong Kong. ${ }^{16}$

Figure 1.Destinations to which women were trafficked as migrants from 2016 to 2017 Primary data: processed

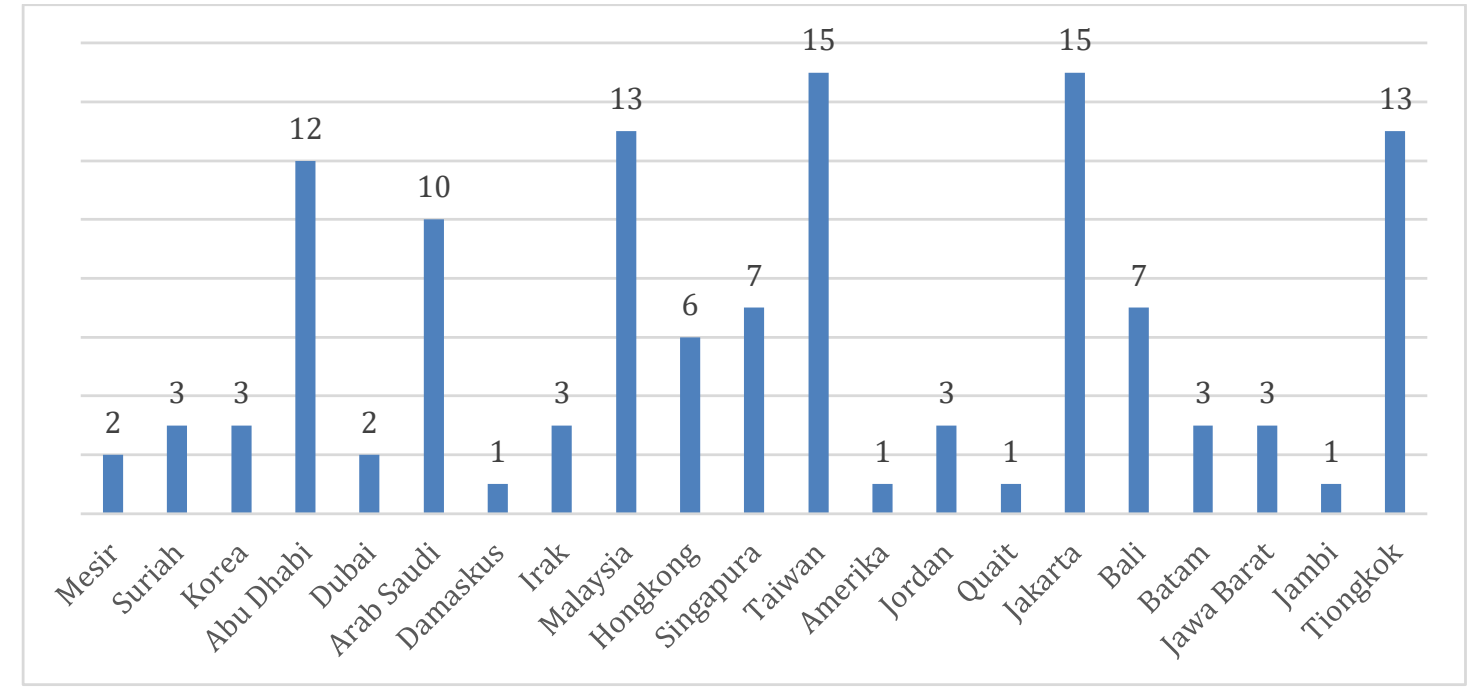

Some other victims of trafficking in Bongas are between 15 and 18 years old. Children at this age group should have their rights to pursue education under the supervision of their parents to assure they accomplish their compulsory education levels as set by the government. This situation also indicates that those becoming the victims are mostly secondary school students or some have not even finished their
14 Lathifah Hanim dan Adityo Putro Prakoso,. 'Perlindungan Hukum Terhadap Korban Kejahatan Perdagangan Orang (Studi Tentang Implementasi Undang-undang Nomor 21 Tahun 2007)', (2015) 2(2) Jurnal Pembaharuan Hukum, p. 236 .
15 An Interview with Syarifudin, Head of Kusuma Bongas Foundation on the $16^{\text {th }}$ of December 2019 in Bongas Indramayu.

16 An interview with Syarifudin, Head of Kusuma Bongas Foundation on the $24^{\text {th }}$ of December 2019 in Bongas, Indramayu 
formal secondary education, as shown in the

figure 2.

Figure 2. Varied Tendencies in Education from 2016 to 2017

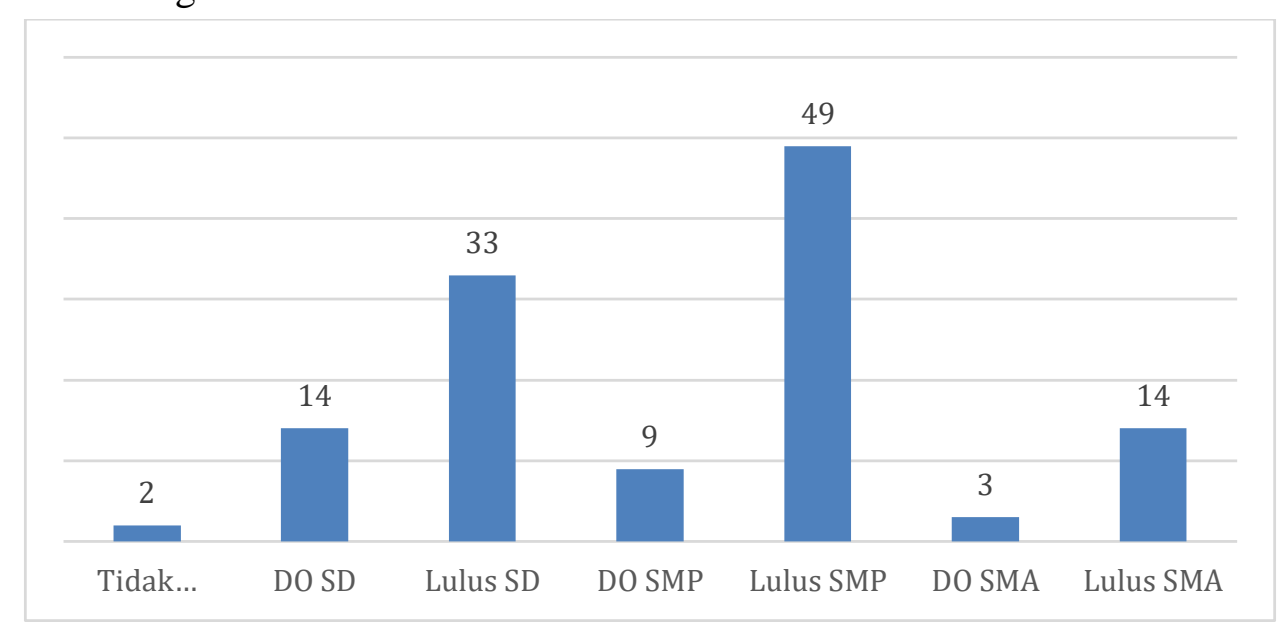

\section{Primary data: processed}

The question "what is the fastest way to tackle trafficking of women' is raised. When the trafficking is revealed, normally law enforcers will immediately carry out investigation and deliver enquiries since this is a criminal case for which police is responsible. However, it requires more than just curative measures to completely clear this issue.

Why do many women in Bongas fall as victims? From the data studied, gender discrimination is the cause of this trafficking, especially in terms of the way people in Bongas think. Many families in Bongas still believe that education is supposed to be for most men instead of for women. It is common to see women only hold their elementary education as their highest education degree, while men usually finish their high school. Moreover, trafficking is Bongas is closely related to the perception or the perspective of the locals implying that women mostly end up as migrant workers

17 An interview with parents of victims of trafficking in Bongas after they are married to reach their maturity before they are ready for work.

When they become a widow, issues often start to come and they will easily become the spotlight in a negative way following their divorce. The status as a widow is often defined as a woman without dignity, holiness, and virginity, and this stigma forces them to flee their neighbourhood as migrants. In such a position, they are often submissive to their parents, doing what their parents wish them to do: becoming migrant workers. ${ }^{17}$

The influential role of parents in persuading their children to work as migrants leads to victimisation in trafficking. In reference to a research, the number of women in trafficking is not due to the women's own expectation, but it rather comes from the strong influence of their parents pushing them into prostitution and trafficking, where it all starts with their deployment in big cities as migrant workers.

A similar issue also took place in Karawang. 18 Organised trafficking of

18 Chandra Purnama, Windy Dermawan, Emil Mahyudin, 'Sosialisasi Mengenai Perdagangan Manusia (Human Trafficking) Dalam Upaya 
children is widely heard, and several villages in the district of Tempuran, the Regency of Karawang have been the source of trafficking. Surprisingly, several parents even support their own children to work as migrant workers, in which money is the main factor of this inhumane encouragement.

Another study also reveals that money often manages to lure them into the darkness. Exploited children often end up as sex workers with the expectation that they will receive five million rupiahs monthly as promised. As told in the interview conducted, some victims are reported to have succeeded to be migrant workers in Jakarta. Several workers coming back from Jakarta often share stories of their success and these stories lure others with the expectation of earning huge amount of money.

Indramayu has been stigmatised as 'luruh duit', and this problem is a social phenomenon that has been around in society, acceptable, and learnt for years. 'Luruh duit' happens because the growing social system fails to fulfil the needs of the locals spiritually, materially, or socially. 'Luruh duit' is accepted and brought into practice as part of the culture by the locals through the process of shared meaning that comprises understanding, definition, situation, vision, value, belief, myth, and even legend in the society. Most people in Indramayu see 'luruh duit' as part of their life, without which they cannot live their life.

On the other hand, 'luruh duit' represents failure, cruelty, injustice, dishonesty, and some other stigmas. This phenomenon deserves attention from all parties since women and children are responsible generation for the future; their dignity deserves protection. Therefore, an organisation or a foundation called Kusuma Bongas in Indramayu was established to resolve trafficking by providing coassistance and development of a rehabilitation program. This program is also supported by Terre des Home Netherlands (TdH NL). The program involves the following activities:

Table Program of Rehabilitation

\begin{tabular}{|c|c|c|c|}
\hline \multirow[t]{5}{*}{1} & Type of services & : & \\
\hline & a. Primary Needs & : & $\begin{array}{l}\text { Providing basic services that are casuistic and occasional and that are } \\
\text { adjusted to the capacity of an organisation }\end{array}$ \\
\hline & $\begin{array}{l}\text { b. Accessibility to } \\
\text { education }\end{array}$ & : & $\begin{array}{l}\text { Establishing open secondary school intended to distract children from } \\
\text { their involvement in trafficking and establishing kejar paket } A \text { (non- } \\
\text { formal education equal to primary school to prepare students for } \\
\text { national exam to get a certificate equal to primary school diploma), } B \\
\text { (equal to secondary school), and } C \text { (equal to high school) for children. }\end{array}$ \\
\hline & $\begin{array}{l}\text { c. Accessibility to } \\
\text { health services }\end{array}$ & : & $\begin{array}{l}\text { Establishing an association with health service providers and } \\
\text { developing referral system of voluntary counselling for HIV-AIDS and } \\
\text { sexually transmitted diseases. Some contributions are made by } \\
\text { organisations, but things have to be adjusted to the capacity of } \\
\text { organisations. }\end{array}$ \\
\hline & d. Birth certificate & : & $\begin{array}{l}\text { Facilitating issuance of birth certificate that is casuistic and occasional. } \\
\text { Some contributions are made by the organisation, but things have to be } \\
\text { adjusted to the capacity of the organisation. }\end{array}$ \\
\hline
\end{tabular}

Pencegahan Tindak Pidana Perdagangan Orang (TPPO)', (2018) 1(2) Jurnal Kumawula, p. 98. 
e. Counselling and : Delivering counselling and coaching such as in fashion (sewing and coaching embroidering), culinary art, and screen printing. Some contributions are made by the organisation.

\begin{tabular}{ll}
\hline Number of co- & The number of co-assistances from 2004 to date is given as follows: \\
assistances & Child Protection Network in 10 villages in 3 districts (Patrol, \\
Anjatan, and Bongas) takes 200 persons \\
- Introducing safe trafficking and migrating in 15 districts for \\
secondary school and high school children. This was addressed \\
to 32,800 persons \\
- $\quad$ Giving information on children's rights, reinforcing children \\
in a family, reinforcing children and families. This was \\
addressed to 465 persons \\
- Giving information on reproduction health and HIV-AIDS to \\
secondary school and high school students. This was addressed \\
to 9,099 persons. \\
Counselling and reference for HIV-AIDS sufferers, addressed \\
to 70 persons. \\
Forming cadres, prevention of trafficking and health \\
reproduction in 15 districts addressed to 770 persons \\
Preventing vulnerable children from trafficking through open \\
secondary school that has educated 14 generations consisting \\
of 465 persons. \\
Repatriating human trafficking victims and conducting \\
reintegration. This was addressed to 326 persons. \\
\end{tabular}

Rehabilitation program was achieved through the following stages:

1. Post assessment that was conducted in Bugis village on the $16^{\text {th }}$ of March 2015 took place in Mrs Darsinah's place involving 11 participants, 6 females and 5 males including adults and children. Post assessment was carried out by means of PGD to find out the figure for kids dropping out of primary school, caused by economic factors, things that forced them to work or get married, discrimination against children, or the state where children were left by their parents to work overseas or left due to divorce, or the state where children were forced to live with their grandmother;

2. Workshop held in Bongas village consisted of 20 children as participants on the $19^{\text {th }}$ of November 2015 from two districts, seven villages involving the district of Bongas, 5 villages and two villages from the district of Anjatan.

3. Children participation was urged to support children at school. This support was given by helping students with funding for their kejar paket $C$, or by supplying them with stationery

4. Reintegration of the victims was performed, involving picking up and monitoring the three victims of trafficking. This measure urged Fitri Wati to join kejar paket $C$, Koliah to join open secondary school, and Susi Susanti to join vocational school, where she decided to join $\mathrm{Al}$ Huda Vocational School but then she dropped it and moved to kejar paket $C$.

\section{CONCLUSION}

Based on the details and discussion above, this research concludes that frequent trafficking in Bongas, Indramayu is triggered 
by poor education, economic hurdles, and social and cultural factor that was indicated by the practice of 'luruh duit'. Furthermore, handling the victims of trafficking in Bongas, Indramayu involves three stages namely first, the identification is performed to find out people or victims exploited in trafficking. Second, rehabilitation is provided as a measure to bring recovery to the victims of trafficking. The time it takes for rehabilitation depends on the condition of the victims. When someone is identified as a trafficking victim, he/she should be sheltered in a safe accommodation or in a house to support the process that follows. If needed, the victim with critical condition can be hospitalised and he/she may not be discharged until he/she gains full recovery. Third, reintegration is intended to help the victims of trafficking to be accepted back in their families and societies.

\section{REFERENCES}

\section{Books}

Atmasasmita, Romli, Masalah Tuntutan terhadap Korban Tindak Pidana, (Jakarta: Badan Pimpinan Hukum Nasional Departemen Kehakiman RI, 1991)

Mansyur, Didik M. Arief \& Elisatris Gultom,

Urgensi Perlindungan Korban Kejahatan: Antara Norma dan Realita, (Jakarta: PT. RajaGrafindo Persada, 2008)

Mulyadi, Lilik, Kapita Selekta Hukum Pidana, Kriminologi dan Viktimologi, (Jambatan, Jakarta, 2007)

Nitibaskara, Tubagus Ronni, Catatan Kriminalitas, (Jayabaya Univercity Press, 1999)

Sahetapy, J.E., Victimologi: Sebuah Bunga Rampai, (Jakarta: Sinar Harapan, 1987)

\section{Journals}

Astuti, Rima, 'Hubungan Kesadaran Akan Kerentanan Diri dan Mekanisme Coping Pada Perempuan Pekerja Malam di Tempat Hiburan Karaoke di Wilayah Jakarta Barat', (2011) 7(11) Jurnal Kriminologi Indonesia

Daniel, Everd Scor Rider, Nandang Mulyana, and Budhi Wibawa, 'Human Trafficking di Nusa Tenggara Timur', (2016) 7(1) Jurnal Social Work

Hanim, Lathifah and Adityo Putro Prakoso, 'Perlindungan Hukum Terhadap Korban Kejahatan Perdagangan Orang (Studi Tentang Implementasi Undangundang Nomor 21 Tahun 2007)', (2015) 2(2) Jurnal Pembaharuan Hukum

Killing, Indra Yohanes and Beatriks Novianti Killing-Bunga, 'Motif, Dampak Psikologis, Dan Dukungan Pada Korban Perdagangan Manusia Di Nusa Tenggara Timur' (2014) 10(10) Jurnal Psikologi Ulayat

Purnama, Chandra, Windy Dermawan, Emil

Mahyudin, 'Sosialisasi Mengenai Perdagangan Manusia (Human Trafficking) Dalam Upaya Pencegahan Tindak Pidana Perdagangan Orang (TPPO)', (2018) 1(2) Jurnal Kumawula

Satriani, Rizka Ari, Tamsil, Muis, 'Studi Tentang Perdagangan Manusia (Human Trafficking) Pada Remaja Putri Jenjang Sekolah Menengah di Kota Surabaya', (2013) 4(1) Jurnal BK UNESA

Soraya, Anis, 'Binahayati Rusyidi dan Maulana Irfan, 'Perlindungan Terhadap Anak dan Korban Trafficking', (2017) 2(1) Prosiding KS. Riset, PKM.

Zaman, Q., 'Sanksi Pidana Perdagangan Perempuan (Women Trafficking) 
(Studi Komparatif Antara Undangundang Nomor 21 Tahun 2007 Tentang Pemberantasan Tindak Pidana
Perdagangan Orang dan Hukum Islam', Raheema, (2017) 2(3) Jurnal Studi Gender dan Anak. 